\title{
Urban space and climate: Introduction to the Special Issue
}

\author{
Miroslav VYSOUDIL a*
}

An urban climate refers to the fact that atmospheric conditions tend to be different in a city compared to the surrounding rural environment. In addition, urban areas constitute those locations most at risk among those affected by potential global climate changes. Studies concerning the impact of global changes on the local climates of cities are of great significance for the health and wellbeing of urban residents. In contrast to the cities of Western Europe, however, urban areas in Central Europe developed in a significantly different way after World War II because of political and economic conditions. Urban structures, then, also tend to be different, and urban climate studies must include those specific features.

This Special Issue of the Moravian Geographical Reports (MGR) includes selected, revised and updated original papers by climatologists and related scientists from the Central European region. Considering the broader geographic focus of the MGR, this issue includes works dealing with urban climate studies from several perspectives, including spatial aspects. The purpose of these introductory remarks is to contextualize this research area in general terms, opening up the field for the reader.

An urban area is a specific geographic space exhibiting many features, including the regime of most meteorological elements and climatic characteristics. According to Landsberg (1981), an urban area, in comparison with a suburban one, is mainly characterised by the following factors: a lower average wind speed; higher daily and annual average air temperatures; lower relative humidity; reduced visibility; a higher value of air pollution because of higher emissions of air pollutants; a reduced value of solar radiation; a higher value of cloudiness; a higher value of total precipitation; an increased frequency of storms; a higher frequency of fog in winter; and a shorter heating season.

These differences manifest themselves most clearly in cities with more than one million inhabitants, but they have also been demonstrated in the smaller towns that are typical of Central Europe (Beranová and Huth, 2006; Bottyán et al., 2005; Bokwa, 2011; Dobrovolný et al., 2012; Unger et al., 2001; Vysoudil et al., 2012). The specific character of the urban climate is also influenced by other more general factors. According to Oke (1981), the most important factors include the thermal and radiation properties of active surfaces, their mostly impermeable character, the geometrical arrangement of active surfaces, waste heat production and pollution of the urban atmosphere.

The study of urban climates is a relatively 'young' field, about two hundred years old. The scientific basis of studies of the climate in cities was established by an English chemist and meteorologist, Luke Howard (1772-1864), who sorted the records of meteorological measurements in London for the period 1797-1831 and in 1833 published the results in his book "Climate of London Deduced from Meteorological Observation" (Howard, 1833). With respect to the further development of urban climatology, it was essential that Howard did not confine himself to monitoring the temperature conditions of London itself, but also observed any differences in comparison with its surroundings. The importance of Howard's contribution to studies of urban climate was emphasised by the Second Edition of his publication by the International Association for Urban Climate (Howard, 2007). The work of Luke Howard has a special place in the history of the field because he was the first to recognise the existence of urban heat islands (UHI) and because his analysis proved to be so prescient. His theory of the manifestations of a warmer urban climate still remains valid today, and Howard is therefore rightly regarded as the principal founder of urban climatology.

The dynamic development of urban climate studies from the mid- $20^{\text {th }}$ century to the present day has been influenced not only by the development of measurement techniques and statistical and mathematical-physical methods of research, but also by the gradual development of space technology, GIS methods and information technologies in general. The attention of scientists has gradually shifted to the study of all meteorological elements and meteorological processes responsible for the formation and character of the urban climate.

The studies of urban climate from the mid- $20^{\text {th }}$ century to the present can be characterised in a broad fashion in the following stages:

- 1960s: employment of statistical methods to test hypotheses, moving towards an energy budget approach and explanations;

- 1970s: application of computer techniques in modelling, observations of energy fluxes, a more rigorous definition of the urban "surface", urban scales and observing urban effects;

- 1980s: adoption of common urban forms for modelling and measurement, the use of so-called physical models, measurement of fluxes in different cities;

- 1990s: establishing relationships between urban forms and their climatic effects, urban field projects examined by research teams; and

- 2000s+: improved models of urban geometry, increased links between modelling and measurement programs.

The most distinctive contributor to urban climatology in second half of $20^{\text {th }}$ century is probably the Canadian climatologist T. R. Oke, who extended the traditional descriptive approach of studies of urban climate to encompass studies of the actual climate-forming processes characteristic of urban areas, and further outlined directions leading to more efficient urban climate research (Oke, 2006a, 2006b). Research in the field of urban climatology therefore pays particular attention to the key area of collecting relevant data needed for subsequent analysis.

\footnotetext{
a Department of Geography, Faculty of Science, Palacký University in Olomouc, Olomouc, Czech Republic (*corresponding author: M. Vysoudil, e-mail: miroslav.vysoudil@upol.cz)
} 
The development of space technology has enabled the use of satellite images from the remote sensing of the Earth in both the microwave and long-wave heat thermal parts of the electromagnetic spectrum for the needs of climatological and environmental research (Adams and Gillespie, 2006). A systematic review of the possibilities of using remote sensing data in urban climatology is presented by Weng and Quattrochi (2007). For the study of spatial-temporal changes in urban heat islands, thermal satellite images have been used by climatologists in virtually all geographic regions (Mesev, 1998; Nichol, 1998; Ozawa et al., 2004; Van, 2007; Weng et al., 2004; Weng, 2009; Yamaguchi and Kato, 2007), and recently also by Czech researchers (Dobrovolný, 2013; Geletič and Vysoudil, 2012; Sedlák et al., 2010).

The absence of historical and recent meteorological data from stationary measurements is a common problem in urban climate studies. Therefore, in the second half of the $20^{\text {th }}$ century mobile measurements began to be used systematically as a new method for obtaining operational meteorological data. Schmidt and Peppler may be considered as the founders of these methods, according to Yoshino (1975). The key work in the field of mobile measurements was presented by Sundborg (1950), whose contribution ranks highly among the methods of studying urban climate, i.e. mobile measurement using a thermometer placed on an automobile. The pioneer of these methods in Central Europe was undoubtedly the Czech climatologist Quitt (1956, 1972).

Oke (1987) states that these methods allowed a better definition and quantification of surface urban heat islands (SUHI) and atmospheric urban heat islands (AUHI). Mobile measurements also allowed UHI to be identified in smaller agglomerations, regardless of their areal extent (Kopec, 1970). They also made possible a detailed understanding of important processes in urban spaces, especially the energy balance (Terjung, 1970). The effectiveness of an integration of multi-level measurement methods, including mobile ones, and the use of different data sources (Hart and Sailor, 2009), has also been demonstrated.

Studies based on mobile measurements are frequent in Central Europe, as evidenced by the following examples. Unger et al. (2001) identified the time of the most prominent manifestation of the UHI in Debrecen (Hungary). The structure of the urban heat island of Ljubljana (Slovenia) was described by Jernej (2000). Mobile air temperature measurements were used to study the links between the fields of temperature, orography and type of active surface in Krakow (Poland) and its outskirts (Bokwa, 2011). Mobile measurement in a study of the influence of orography and spatial structure on the urban climate of the city of Košice and its surroundings (Slovakia) was employed by Štastný (1996). Similarly, Polčák and Soták (2002) studied the climate of Banská Bystrica (Slovakia). In 2010-2012, mobile measurements and stationary measurements also took place simultaneously in the Czech Republic (Olomouc, Brno), where, for example, they enabled the point of origin of the potential climatic effects to be located (Vysoudil, 2010). A similar study was published by Dobrovolný et al. (2012), using the case of Brno (Czech Republic).

The lack of meteorological data from standard measurements is to some extent compensated by measurements from purpose-built networks of stations. The organisational and financial demands on measurements in purpose-built station networks often result in their being operated for only a short time. In Central Europe, such short-term measurements have been realised, for example, in Slovenia (Ljubljana), Austria (Graz), Poland (Krakow) and Hungary (Debrecen). The long-term existence of station networks suitable for the needs of urban climate studies is rather rare. One example in Central Europe is the network of urban stations in the Czech Republic (Vysoudil et al., 2012; Dobrovolný et al., 2012).

In recent decades, dynamic computerisation, increasingly sophisticated mathematical-physical and statistical methods, digital equipment and measurement technologies, have all contributed to the creation of numerical climate models (Kusaka et al., 2001; Lemonsu et al., 2004; Mills, 1997). Because of their increasing spatial resolution, they are applicable even at the level of the meso-, local and micro-scales, i.e. the spatial levels that are usual for the study of urban climate (Baklanov and Nuterman, 2009). Even the majority of the first 2D models from the period 1970-2000 enable city heat islands to be determined in a reliable manner.

Recently these models have been refined and 3D models are becoming standard. They are irreplaceable, especially for the study of urban circulation resulting from the complicated morphographies of urban relief (Bornstein et al., 1993; Yoshikado, 1992) and their spatial structures (Swaid, 1993). The most comprehensive models used in UHI studies use 3D parameters including the shapes of urban development, which allows the energy balance to be studied in detail and separately for individual parts of buildings both in relation to the actual active surface (2D) or to the adjacent layers of the atmosphere (3D): see Masson et al. (2002), Kusaka et al. (2001) and Souch and Grimmond (2006). Simultaneously, empirical models have been developed that are applicable for the study of relationships between cities and their surroundings (e.g. Haffner and Kidder, 1999).

Current models provide a tool for understanding the mechanisms of the formation of urban and suburban climates, including their mutual links, especially their energetic relationships (Masson, 2006). When modelling the urban climate in Central Europe, an often-used micro-scale numerical model is ENVI-met, mesoscale model WRF, and also 2D model MUKLIMO (Sievers and Zdunkowski, 1986), or its 3D version MUKLIMO-3 (Sievers, 1990, 2014). Many of today's models used layers or matrices for modelling. On the scale of a city, their use may be problematic as a result of the large spatial variability of the urban environment and the factors that affect it. Boufidou et al. (2011) therefore distinguish static factors (reflecting the nature and properties of surfaces and objects) and dynamic ones (measured using instruments). Both groups of factors and their role in the formation of urban climates have been described in detail, for example by Kay and Davies (2008) and Stewart and Oke (2009a, 2009b). The majority of current models have the capacity to be used in 3D modelling. A representative survey of modelling processes in the atmosphere at the meso-scale level (cities) is provided by Pielke (2013).

Currently, knowledge about radiation and energy balance seems to be necessary to understand the temperature field of cities and their surroundings. The findings on the energy balance of the city and the spatial structure of the urban atmosphere, as described by Oke (1987), are still applicable. Oke defined the so-called "urban canopy layer - UCL" as the ground layer of the atmosphere immediately above the active surface, with its upper limit approximately at the height of the roofs. Above the UCL, he defined the so-called "urban boundary layer - UBL", creating the urban boundary layer 
of the atmosphere. In the field of the energy balance of a city, Oke's work has been developed by many other researchers (e.g. Gleugh and Oke, 1986; Grimmond, 1992).

Following current views on the formation and nature of the urban climate, it cannot be described only on the basis of the values of measured elements. It must be observed in the context of the character of the surrounding geographic environment of the stations and specific local features. In the last two decades, the description and classification of urban climate has been based on the definition of urban climate zones (UCZ), or local climate zones (LCZ). The classification is based, among other things, on the standardisation of meteorological stations in purposebuilt networks. One of the possible ways of standardising stations according to the structure of the city around them is the definition of LCZ elaborated by Stewart and Oke (2009, 2012). The current classification of LCZ suggested by Steward and Oke (2012) includes 10 classification parameters, including values of geometric and surface cover properties as values of thermal, radiative and metabolic properties. This approach to urban climate classification has been applied gradually in the (Central) European area (e.g. Houet and Pigeon, 2011; Lehnert et al., 2014; Savić et al., 2013; Unger et al., 2014).

Urban climatology includes application layers (urban planning, urban design, urban environmental adaptation, and others). The study of the impact of extreme weather conditions on the health of urban populations is currently very important, and not only in the context of global climate changes. Probably the most frequent topic is the impact of heatwaves, whose frequency has rapidly increased in Europe since 1990 (Solomon et al., 2007). The relationship between heat extremes and increased mortality of the urban population, combined with the UHI effect, has been described by many authors all over the world (inter alia: Gabriel and Endlicher, 2011; Páldy et al., 2005; Smoyer et al., 2000). It has gradually become clear that the risk group in connection with extremely high temperatures is the urban population, but on the contrary, that low temperatures represent an increased danger for the rural population (Conlon et al., 2011; Gómez-Acebo et al., 2010). The impacts of adverse weather conditions on health may be amplified by socio-economic and demographic factors (e.g. Hattis et al., 2012; Sheridan and Dolney, 2003; Wu et al., 2010). These factors are associated with increased mortality in urban populations at both the global and local levels (Dessai, 2002; Karl and Knight, 1997; Schär et al., 2004). Their manifestations and impacts in the Czech Republic can be found, for example, in the work of Huth et al. (2000), Kyselý and Dubrovský (2005), and Kyselý and Kř́̌ž (2008).

In the sense of the activities of the IAUC (International Association for Urban Climate), the current trends in urban climatology include the following research topics: (i) climate change mitigation and adaptation in urban environments; (ii) transfer of urban knowledge to urban planners; (iii) the study of urban climate; (iv) geospatial datasets; (v) new observational and modelling techniques and methods to study urban climates; (vi) bioclimatology and the public; (vii) urban design that takes climate into consideration; (viii) urban planning that takes climate into consideration; and (ix) an interdisciplinary approach.

Contextualized by these topics, this Special Issue is also related to the increased activities of Czech climatologists in the topic of urban climatology, and in the context of the research project: "Multilevel analysis of the urban and suburban climate taking medium-sized towns as an example" (Reg. CZ 205/09/1297). This research project was developed by means of an effectively close national collaboration in research on urban climate, with the idea of supporting international cooperation not only in the Central European area but also beyond.

The Editors of MGR consider this monothematic issue a contribution to the IX International Conference on Urban Climate, Jointly with the XII Symposium on the Urban Environment, held in July 2015 in Toulouse (France). In a broader sense, this Special Issue of MGR develops monothematic issues devoted to urban climate published in recent years in Central Europe in Geographia Polonica 2014, 87(4) and Geographica Pannonica 2013, 17(3).

When selecting articles, a preference was afforded to those papers that addressed some of the major problems in modern urban climatology.

In the first three articles, the authors represent more strictly areas of research in climatology. In the first paper, Petr Dobrovolný and Lukáš Krahula investigate the spatial variability of air temperature and nocturnal urban heat island intensity in the city of Brno, Czech Republic, with respect to a number of factors such as altitude, quantity of vegetation, density of buildings and the structure of the transportation (road) system. The main information sources consist of mobile air temperature measurements and a relevant geographical database.

The second article presents a comparative case study of air temperature in three major urban settlements in Italy, Slovenia and Croatia, using 100-year trends, evaluated by Darko Ogrin. Differences in trends between Ljubljana (Slovenia) and Zagreb (Croatia) result in part from different measurement histories, but the impact of urban climates is also presented. The lowest air warming trends occur in the maritime climate of Trieste (Italy), where measurements were continuously performed in the densely built-up section of the city.

In the third paper by Katja Vintar Mally and Matej Ogrin, the data from two measuring campaigns throughout the city of Ljubljana (Slovenia) during the summer of 2013 and the winter of 2014, were used for an analysis of spatial variations of $\mathrm{NO}_{2}$ concentrations. Since the main source of $\mathrm{NO}_{2}$ in Ljubljana is road transport, three types of urban space have been identified (urban background, open space along roads, and street canyon), and their $\mathrm{NO}_{2}$ pollution levels were measured using Palmes diffusive samplers at a total of 108 measurement points. The results of both measuring campaigns allowed a precise estimation of the pollution levels of different types of urban space.

The subsequent four papers represent broader aspects of climatological research in East Central Europe, with work related to urban areas. The paper by Márton Kiss, Ágnes Takács, Réka Pogácsás and Ágnes Gulyás presents the problems of natural system responses to reducing pollution in urban space. The effects of differences in tree management on the chosen ecosystem services were investigated by comparing two pairs of tree alleys in the town of Szeged (Hungary).

A contribution to the topic of social system responses to the specific climate in urban space is presented in the article by Hana Středová, Tomáš Středa and Tomáš Litschmann, which deals with role of smart tools of urban climate evaluation for smart spatial planning. Data over the period 2011-2014 were collected, analyzed, and used for comparison and modelling purposes. As commonly accepted, the use of standard climate 
information has a low priority for urban planners. Hence, the authors calculated the HUMIDEX index, as information that could be more understandable with respect to temperature conditions for urban planners.

On a related topic, Dalibor Výberči, Marek Švec, Pavol Faško, Henrieta Savinová, Milan Trizna and Eva Mičietová explore heat-related human mortality for the total population, as well as within selected population groups, in Slovakia over the period 1996-2012, for the case of summer heat events. This paper is one of the first of its kind focusing on the given population and sub-groups in Slovakia.

The final paper in this Special Issue is by Lívia Labudová, Pavol Faško and Gabriela Ivaňáková, who discuss some of the larger-scale changes in different climatic regions for the case of Slovakia. Most studies comparing recent climate conditions to the past, use as the reference period the years from 1961 to 1990. In this article, the authors to point out the probable characteristics for the next reference period from 1991 to 2020 . Finally, changes in the climate regions in Slovakia are analysed, comparing the spatial distributions in both reference periods.

The articles presented in this Special Issue illustrate both the theoretical and empirical aspects of urban spaces and their specific climates. In summary, the global climate is changing and this reality is reflected in the changes in urban climates, which also contribute to global changes.

\section{Acknowledgement}

Research for this article and editorial work on the Special Issue was implemented in the scope of the project "Multilevel analysis of the urban and suburban climate taking mediumsized towns as an example" (Reg. CZ 205/09/1297) financed by the Czech Science Foundation. The author would like to thank Prof. Petr Dobrovolny and Prof. Bryn-Greer-Wootten for their helpful comments on a draft manuscript.

\section{References:}

ADAMS, J. B., GILLESPIE, A. R. (2006): Remote Sensing of Landscapes with Spectral Images: A Physical Modelling Approach. Cambridge University Press.

BAKLANOV, A. A., NUTERMAN, R. B. (2009): Multi-scale atmospheric environment modelling for urban areas. Adv. Sci. Res., 3: 53-57.

BERANOVÁ, R., HUTH, R. (2005): Long term changes of the heat island of Prague under different synoptic conditions. Theoretical and Applied Climatology, 82: 113-118.

BOKWA, A. (2011): The Urban Heat Island in Krakow, Poland: Interaction Between Land Use and Relief. Moravian Geographical Report, 19(3): 2-7.

BORNSTEIN, R., THUNIS, P., SCHAYES, G. (1993): Invited Paper Simulation of urban barrier effects on polluted urban boundary layers using the threedimensional URBMET/TVM model with urban topography - new results from New York City. Computational Mechanics Publications, Ashurst Lodge, Ashurst, Southampton, 15-34.

BOTTYÁN, Z., KIRCSI, A., SZEGEDI, S., UNGER, J. (2005): The relationship between built-up areas and the spatial development of the mean maximum urban heat island in Debrecen, Hungary. International Journal of Climatology 25: 405-418.
BOUFIDOU, E., COMMANDEUR, T. J. F., NEDKOV, S. B., ZLATANOVA, S. (2011): Measure the Climate, model the City. In: Fendel, Ledoux, Rumor\&Zlatanova [eds.]: Proceedings of the $28^{\text {th }}$ UDMS, International Archives of the Photogrammetry, Remote Sensing and Spatial Information Sciences, Volume XXXVIII-4/C21: 59-66.

CONLON, K. C., RAJCHOVICH, N. B., WHITE-NEWSOME, J. L., LARSEN, L., O'NEILL M. S. (2011): Preventing cold-related morbidity and mortality in a changing climate. Maturitas, 69: 197-202.

DESSAI, S. (2002): Heat stress and mortality in Lisabon. Part I. Model construction and validation. International Journal of Biometeorology, 48(1): 37-44.

DOBROVOLNÝ, P. (2013): The surface heat island in the city of Brno (Czech Republic) derived from land surface temperatures and selected reasons for its spatial variability. Theoretical and Applied Climatology. 112 (1-2): 89-98.

DOBROVOLNÝ, P. et al. (2012): Klima Brna. Víceúrovňová analýza městského klimatu. Masarykova Univerzita, Brno.

GABRIEL, K. M., ENDLICHER, W. R. (2011): Urban and rural mortality rates during heat waves in Berlin and Brandenburg, Germany. Environmental Pollution, 159: 2044-2050.

GELETIČ, J., VYSOUDIL, M. (2012): Analysis of surface temperatures in urban and suburban landscapes from satellite thermal images: a case study of Olomouc and its environs, Czech Republic. Moravian Geographical Reports, 20(1): 55-69.

GLEUGH, H. A.; OKE, T. K. (1986):Suburban-rural balance comparisons in summer for Vancouver, B.C. Boundary Layer Meteorology, 36(4): 351-370.

GÓMEZ-ACEBO, I., DIERSSEN-SOTOS, T., LLORCA, J. (2010): Effect of cold temperatures on mortality in Cantabria (Northern Spain): a case-crossover study. Public Health, 124(7): 398-403.

GRIMMOND, C. S. B. (1992): The suburban energy balance: methodological considerations and results for a midlatitude west coast city under winter and spring conditions. International Journal of Climatology, 12: 481-497.

HAFFNER, J., KIDDER, S. Q. (1999): Urban Heat Island Modelling in Conjunction with Satellite-Derived Surface/ Soil Parameters. Journal of Applied Meteorology and Climatology, 38(4): 448-465.

HART, M. A., SAILOR, D. J. (2009): Quantifying the influence of land-use and surface characteristics on spatial variability in the urban heat island. Theoretical and Applied Climatology, 95(3-4): 397-406.

HATTIS, D., OGNEVA-HIMMELBERGER, Y., RATICK, S. (2012): The spatial variability of heat-related mortality in Massachusetts. Applied Geography, 33: 45-52.

HUTH, R., KYSELÝ, J., POKORNÁ, L. (2000): A GCM simulation of heat waves, dry spells, and their relationship to circulation. Climatic Change, 46 (1-2): 29-60.

HOUET T., PIGEON G. (2011): Mapping urban climate zones and quantifying climate behaviours - An application on Toulouse urban area (France). Environ. Pollut., 159(8-9): 2180-2192.

HOWARD, L. (2007): The Climate of London. IAUC edition available at www.lulu.com in two volumes. 
HOWARD, L. (1883): The Climate of London, Deduced from Meteorological Observations, Made at Different Places in the Neighbourhood of the Metropolis. 2 vols. London: W. Philips 1818-1820. Rev. Ed.

JERNEJ, S. (2000): Planungsrelevante Stadtklimaanalyze Laibach / Ljubljana. Graz, Ph.D. Thesis. Karl-Franzens Universität, Graz.

KARL, T., KNIGHT, R. (1997): The 1995 Chicago Heat wave: How likely is a recurrence? Bulletin of American Meteorological Society, 78(6): 11007-1119.

KOPEC, R. J. (1970): Further Observations of the Urban Heat Island in a Small City. Bulletin of the American Meteorological Society, 51(7): 602-606.

KUSAKA, H., KONDO, H., KIKEGAWA, Y., KIMURA, F. (2001): A simple single-layer urban canopy model for atmospheric models: Comparison with multilayer and slab models. Boundary-Layer Meteorology, 101(3): 329-358.

KYSELÝ, J., DUBROVSKÝ, M. (2005): Simulation of extreme temperature events by a stochastic weather generator: effects if interdiurnal and interannual variability reproduction. International Journal of Climatology, 25(2): 251-269.

KYSELÝ, J., KŘÍŽ, B. (2008): Decreased impacts of the 2003 heat waves on mortality in the Czech Republic: an improved response? International journal of biometeorology 52(8): 733-745.

LANDSBERG, H. E. (1981): The Urban Climate. New York, Academic Press.

LEHNERT, M., GELETIČ, J., HUSÁK, J., VYSOUDIL, M. (2014): Urban field classification by "local climate zones" in a medium-sized Central European city: the case of Olomouc (Czech Republic). Theoretical and Applied Climatology (pp. 1-11). Wien, Springer-Verlag. DOI: 10.1007/s00704-014-1309-6.

LEMONSU, A., GRIMMOND, C. S. B., MASSON, V. (2004): Modelling the surface energy balance of an old mediterranean city: Marseille. Journal of Applied Meteorology, 43(2): 312-327.

MASSON, V., GRIMMOND, C. S. B., OKE, T. R. (2002); Evaluation of the Town Energy Balance (TEB) scheme with direct measurements from dry districts in two cities. Journal of Applied Meteorology, 41: 1011-1026.

MASSON, V., (2006): Urban surface modelling and the meso-scale impact of cities. Theoretical and Applied Climatology, 84: 35-45.

MESEV, V. [ed.]. (2003): Remotely sensed cities. Taylor and Francis, London and New York.

MILLS, G. (1997): An urban canopy-layer climate model. Theoretical and Applied Climatology, 57(3-4): 229-244.

NICHOL, J.E. (1998): Visualisation of urban surface temperatures derived from satellite images. International Journal of Remote Sensing, 19(5): 1639-1649.

OKE, T. R. (1987): Boundary Layer Climates. Methuen, London.

OKE, T. R. (1981): Canyon geometry and the nocturnal heat island: comparison of scale model and field observations. Journal of Climatology, 1(3): 237-254.
OKE, T. R. (2006a): Initial guidance to obtain representative meteorological observations at urban sites. IOM Report No. 81, WMO/TD No. 1250.Geneva, World Meteorological Organization.

OKE, T. R. (2006b): Towards better scientific communication in urban climate. Theoretical and Applied Climatology, 84: 179-190.

OZAWA, A. et al. (2004): Airborne hyperspectral and thermal information for assessing the heat island in urban areas of Japan [online]. [cit. 10.09.2007]. Available at: http://www.isprs.org/istanbul2004/comm7/ papers/9.pdf

PÁLDY, A., BOBVOS, J., VÁMOS, A., KOVATS, R.S., HAJAT, S. (2005): The effect of temperature and heat waves on daily mortality in Budapest, Hungary, 1970- 2000. In: Kirch, W., Menne, B., Bertollini, R. [eds.)] Extreme Weather Events and Public Health Responses (pp. 99-107). World Health Organization. Berlin, Springer.

PIELKE Sr., R.A. (2013): Meteorological Modelling. 3rd Edition. Academic Press, Elsevier Inc.

POLČÁK, N., SOTÁK, Š. (2002): Analýza terénnych meraní teploty vzduchu v Banskej Bystrici. In. Baran, V:: Banská Bystrica v geografickej realite času a priestoru: 152-159.

QUITT, E. (1956): Př́íspěvek k metodice výzkumů teplotních poměrů měst. Meteorologické zprávy, 1: 69-74.

QUITT, E: (1972): Měřícíjízdy jako jedna z cest k racionalizaci mezoklimatického výzkumu. Meteorologické zprávy, 26(6): 172-176.

SEDLÁK, P., PRISLINGER, J., VYSOUDIL, M. (2010): Využití dat $\mathrm{z}$ družice LANDSAT pro detekci tepelného znečištění v městské a příměstské krajině. In: Scientific Papers of the University of Pardubice - Series D 16. (1/2010) (pp. 264-278). Pardubice, Univerzita Pardubice, Faculty of Economics and Administration.

SAVIĆ, S., MILOŠEVIĆ D., LAZIĆ L., MARKOVIĆ V., ARSENOVIĆ D. P. (2013): Classifying Urban Meteorological Stations Sites by "Local Climate Zones": Preliminary Results for the City of Novi Sad (Serbia). Geographica Pannonica, 17(3): 60-68.

SHERIDAN, S. C., DOLNEY, T. J. (2003): Heat, mortality, and level of urbanization: measuring vulnerability across Ohio, USA. Climate Research, 24: 255-265.

SCHÄR, C., VIDALE, P.L., LÜTHI, D., FREI, C., HÄBERLI, C., LINIGER, M. A., APPENZELLER, C. (2004): The role of increasing temperature variability in European summer heatwaves. Nature, 427(6972): 332-336.

SIEVERS, U., ZDUNKOWSKI, W. (1986): A microscale urban climate model. Beitr. Phys. Atmosph. 59: 13-40.

SIEVERS, U. (1990): Dreidimensionale Simulationen in Stadtgebieten. Umweltmeteorologie: Sitzung des Hauptausschusses II am 7. und 8. Juni 1990 in Lahnstein. Schriftenreihe Band 15: 36-43. Düsseldorf, Kommission Reinhaltung der Luft im VDI und DIN.

SIEVERS, U. (2014): Das kleinskalige Strömungsmodell MUKLIMO_3 Teil 2: Thermodynamische Erweiterungen. Berichte des Deutschen Wetterdienstes Entwurf, Offenbach am Main, Germany. 
SMOYER, K. E., KALKSTEIN, L. S., GREENE, J. S., YE, H. (2000): The impacts of weather and pollution on human mortality in Birmingham, Alabama and Philadelphia, Pennsylvania. International Journal of Climatology, 20(8): 881-897.

SOLOMON, S., QIN, D., MANNING, M., MARQUIS M., AVERYT, K., TIGNOR, M. M. B., LeROY MILLER, H., Jr. (2007): Climate Change 2007: The Physical Science Basis, Cambridge University Press, Cambridge, New York, Melbourne, Madrid, Cape Town, Singapore, Săo Paulo, Delhi.

SOUCH, K., GRIMMOND, S. (2006): Applied climatology: urban climate. Progress in Physical Geography, 30(2): 270-279.

STEWART, I. D., OKE T. R. (2009): Conference notebook A new classification system for urban climate sites. Bulletin of the American Meteorological Society 90: 922-923.

STEWART, I. D., OKE T. R. (2012): Local Climate Zones for Urban Temperature Studies Bull. Amer. Meteor. Soc., 93: 1879-1900.

SUNDBORG, A. (1950): Local Climatological Studies of the Temperature Conditions in an Urban Area. Tellus, 2: $222-232$

SWAID, H. (1993): Urban climate effects of artificial heat sources and ground shadowing by buildings. International Journal of Climatology, 13(7): 797-812.

ŠŤASTNÝ, P. (1996): Výsledky mobilných meraní teploty a vlhkosti vzduchu v Košiciach. Zborník prác SHMÚ 39: 79-111. Bratislava, Slovenský hydrometeorologický ústav.

TERJUNG, W. H. (1970): The Energy Balance Climatology of a City-Man System. Annals of the Association of American Geographers, 60(3): 466-492.
UNGER, J., SÜMEGHY, Z., ZOBOKI, J. (2001): Temperature cross-section features in an urban area. Atmospheric Research 58: 117-127.

UNGER, J., LELOVICS, E., GÁL, T. (2014): Local Climate Zone mapping using GIS methods in Szeged. Hungarian Geographical Buletin, 63(1): 29-41.

VYSOUDIL, M. (2010): Místní klimatické efekty: Výskyt a projevy v městské a krajině. Geographia Cassoviensis. 4(1): $176-179$.

VYSOUDIL, M. et al. (2012): Podnebí Olomouce. Climate of Olomouc. Vydavatelství Univerzity Palackého, Olomouc.

WENG, Q., LU, D., SCHUBRING, J. (2004): Estimation of land surface temperature-vegetation abundance relationship for urban heat island studies. Remote Sensing of Environment, 89: 467-483.

WENG, Q., QUATTROCHI, D. A. (2007): Urban Remote Sensing. CRC Press, Taylor \& Francis Group, LLC.

WENG, Q. (2009): Thermal infrared remote sensing for urban climate and environmental studies: Methods, applications, and trends. ISPRS Journal of Photogrammetry and Remote Sensing, 64(4): 335-344.

WU, P. C., LIN, C. Y., LUNG, S. C., GUO, H. R., CHOU, C. H., SU, H. J. (2010): Cardiovascular mortality during heat and cold events: determinants of regional vulnerability in Taiwan. Occup Environ Med., 68: 525-530.

YAMAGUCHI, Y., KATO, S. (2007): Using ASTER Data to Study the Urban Heat-Island Effect. The Earth Observer, 19(4): 4-7.

YOSHIKADO, H. (1992): Numerical Study of the Daytime Urban Effect and Its Interaction with the Sea Breeze. Journal of Applied Meteorology, 31(10): 1146-1164.

YOSHINO, M. M. (1975): Climate in a small area. An introduction to Local Meteorology. Tokyo, University Tokyo Press.

\section{Please cite this article as:}

VYSOUDIL, M. (2015): Urban space and climate: Introduction to the Special Issue. Moravian Geographical Reports, 23(3): 2-7. DOI: 10.1515/ mgr-2015-0012. 